\title{
Desain Panel Absorpsi Difusor Bunu
}

\author{
Indradjaja Makainas ${ }^{1}$, Rieneke Lusia Evani Sela ${ }^{2}$ \\ ${ }^{1}$ Fakultas Teknik, Jurusan Arsitektur, Universitas Sam Ratulangi \\ ${ }^{2}$ Fakultas Teknik, Jurusan Arsitektur, Universitas Sam Ratulangi \\ indrakustik@gmail.com
}

\begin{abstract}
Abstrak
Panel Absorpsi Difusor Bunu adalah panel akustik yang berfungsi sebagai penyerap sekaligus pemencar bunyi yang terbuat dari sabut kelapa (bunu). Panel ini digunakan untuk mendapatkan Waktu Dengung (ReveberationTime) sesuai standar kenyamanan pendengaran didalam ruang teater rumah (home theater), ruang karaoke, studio penyiaran radio, studio rekaman, ruang kelas/siding, ruangi badah, auditorium. Bunu sebagai bahan yang melimpah di seluruh pelosok Nusantara yang dikenal dengan sebutan kepulauan Nyiur Melambai perlu dimaksimalkan pemanfaatannya. Didaerah umumnya bunu hanya dijadikan sebagai bahan bakar memasak, malah menjadi limbah dari hasil pengolahan kopra. Panel dikerjakan di AKAS desa Rantewringin kabupaten Kebumen provinsi Jawa Tengah dengan cara manua lkecual idalam menguraikan sabut kelapa menjadi serat (coirfibre) dan serbuk (cocopeat). Bahan pembuat panel adalah seratnya yang disusun berlapis. Panel dibuat dalam 2 (dua) jenis terdiri dari yang datar yang disebut panel indrabunu 01 dan piramida disebut indrabunu 02, untuk mendapatkan nilai koefisien serap $\alpha y a n g$ berbeda. Pengujian nilai $\alpha$ dari panel dilakukan di Laboratorium Akustik Pusat Penelitian Metrologi LIPI Serpong.
\end{abstract}

Kata kunci : bunu, panel, absorpsi, difusor

\section{Pendahuluan}

Penelitian tentang panel penyerap bunyi dari bahan bunu masih kurang bahkan di provinsi Sulawesi Utara belum pernah dilakukan.

Seperti diketahui penelitian yang sudah ada ialah oleh Khuriati, Ainie dan Nur, Muhammad dan Komaruddin dengan judul Disain Peredam Suara Berbahan Dasar Sabut Kelapa dan Pengukuran Koefisien Penyerapan Bunyinya yang dipublikasi di jurnal BERKALA FISIKA, 9 (1). Pp. 15-25. ISSN 1410 - 9662 pada tahun 2006 Universitas Diponegoro Semarang, juga dari Universiti Kebangsaan Malaysia yang berjudul Acoustic Properties of Multi-Layer Coir Fibers Sound Absorption Panel oleh R. Zulkifli, M.J.Mohd Nor, M.F. Mat Tahir, A.R. Ismail dan M.Z. Nuawi yang dimuat pada jurna lApplied Sciences, 8: 3709-3714 tahun 2008. Hasi penelitian yang di temukan oleh tim peneliti UNDIP ialah $\alpha=0,51$, oleh peneliti dari UKM mendapat $\alpha=0,7-0,85$ untuk rentang frekwensi 500-2500 Hz, ini belum mencapai $\alpha$ maksima lkarena masih setara dengan rockwool dan serat sintetis (synthetic fibers) glass wool yang umum dijual di pasaran,

Pemahaman tentang kenyamanan akustik di lingkungan masyarakat terutama pada negara yang sedang berkembang seperti Indonesia belum begitu dimengerti, oleh ebab itu perlu adanya informasi berupa penelitian untuk menunjukan bagaimana manusia bias hidup nyaman dalam menikmati percakapan atau pidato, music didalam ruang tertutup maupun terbuka. 
Ketergantungan kepada bahan sejenis yang diproduksi di luar negeri serta dari bahan sintetis yang bias merusak lingkungan perlu diatasi dengan memanfaatkan bahan terbuang yang banyak terdapat dimana-mana di Indonesia yaitu bunu yang punya kelebihan karena mempunyai karakter berserat (coirfibre), serbuk (cocopeat) dan berpori sehingga cocok untuk dibuat sebagai bahan penyerap bunyi.

Pembuatan panel penyerap buny idari bunu dilakukan secara manual, gampang oleh masyarakat setempat pria maupun wanita sehingga dapat menjadi solusi dalam memberdayakan sumber daya manusia dalam mengentaskan kemiskinan.

Kebutuhan akan panel penyerap bunyi semakin tinggi karena kebutuhan masyarakat yang ingin menikmati music dirumah dengan membuat teater rumah (home theater), studio karaoke, studio radio/TV. Panel penyerap bunyi ini berfungsi juga sebagai bahan dekorasi ruang interior untuk itu penampilannya harus idesain dengan penampilan yang artistic atau diekspos seadanya sebagai penampilan alamiah. Untuk lebih memasyaratkan kenyamanan akustik dengan penataan yang menggunakan bahan bunu, maka diperlukan aplikasi penataan akustik dengan bahan panel akustik tersebut di kalangan mahasiswa Unsrat juga bagi masyarakat di provinsi Sulawesi Utara dan sekitarnya.

\section{Bahan dan Metode}

\subsection{Perambatan Bunyi}

Dasar dari mekanisme perambatan bunyi didalam Ruangan Tertutup terdapat empat fenomena yang ada pada proses perambatan bunyi yaitu: pemantulan (reflection), penyerapan (absorption), difraksi (diffraction), perpencaran (diffusion)

Perambatan bunyi terdiri dari dua jenis yaitu yang menimpa secara tegak lurus pada bidang yang dituju (vertical propagation) dan yang membuat sudut terhadap bidang pemantul (oblique propagation). Jika disekitar sumber bunyi dan pendengar terdapat bidang pemantul maka pendengar akan mendengar bunyi langsung dan bunyi pantulan seperti pada Gambar 1 dimana didalam sebuah Auditorium konser ada empat lintasan bunyi pantulan yaitu dari dua sisi dinding $\left(\mathrm{R}_{1}\right.$ dan $\left.\mathrm{R}_{2}\right)$, plafond $\left(\mathrm{R}_{3}\right)$ dan dari belakang panggung $\left(\mathrm{R}_{4}\right)$. Namun pemantulan bisa juga terjadi dari balkon, dinding belakang, dan bidang pemantul lainnya.

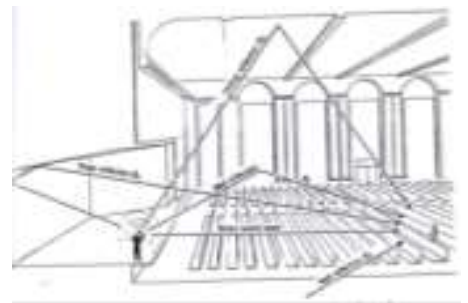

Gambar 1. Lintasan Bunyi Langsung dan Bunyi Pantulan

(Sumber: Beranek, 1962)

Apabila pantulan bunyi berlangsung lama akibat kerasnya bidang didalam ruangan maka akan terjadi dengung yang berkepanjangan sehingga menganggu pembicaraan karena tertutup oleh dengung yang mempunyai RT (Waktu Dengung) lama. Untuk mencegah terjadinya RT yang lama maka diperlukan bahan penyerap bunyi yang ditempel pada dinding, digantung serta menutup lantai.

\subsection{Pemantulan bunyi}

Terjadi jika gelombang bunyi menimpa salah satu pembatas ruangan, maka sebagian energinya akan dipantulkan dari permukaannya, sebagian diserap dan bagian 
lainnya ditransmisi. Semakin masif permukaan bidang maka semakin tinggi bagian energi bunyi yang terpantul konsekwensinya energi bunyi yang terserap dan ditransmisi menjadi lebih kurang. Ini dapat dilihat pada Gambar 2 berikut ini yang sifatnya sama dengan terjadi pada energi gelombang air laut.
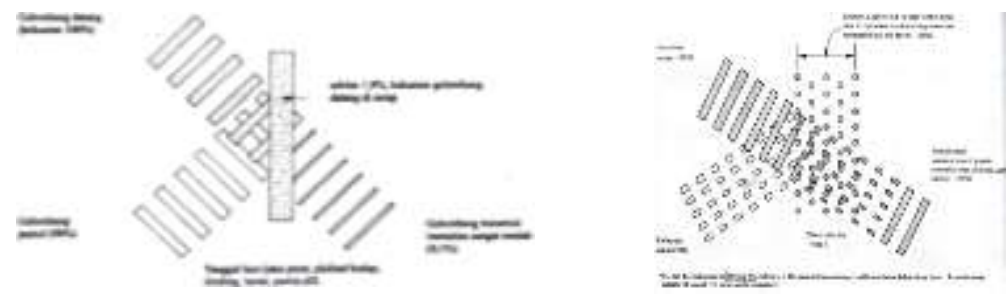

Gambar 2. Pemantulan, Penyerapan dan Transmisi Bunyi (Egan,1972)

\subsection{Penyerapan bunyi}

Penyerapan bunyi terjadi jika permukaan bidang adalah lembut berpori yang mana sangat banyak menyerap getaran buny,i tetapi ini sangat buruk untuk pemantul bunyi. Penyerapan bunyi didalam ruangan adalah ketika energi bunyi hilang disaat menimpa permukaan bidang pembatas ruangan.

Tipe utama dari penyerap bunyi yaitu : bahan berpori, Penyerap membran (panel). Lihat Gambar 3.

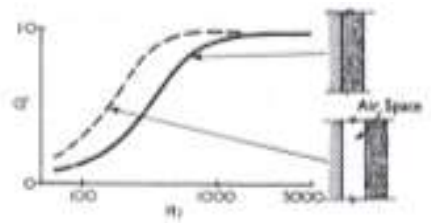

Gambar 3. Karaktristik Penyerapan dari Penyerap Berpori (Parkin, 1969)

Bahan yang dipakai pada tipe penyerap berpori ini adalah papan fiber, wool, blanket insulasi dan sebagainya.

Untuk tipe penyerap bunyi panel ini biasanya memakai bahan seperti panel plafond gantung yang biasanya menggunakan pegas ( agar ikut beresonansi) , jendela ganda, dan sebagainya.

\subsection{Difusor}

Difusor dipakai untuk mengatasi gema didalam ruangan dipergunakan untuk membehahi ketimpangan / penataan bunyi didalam ruangan seperti gema. Sebagai alternatif atau pelengkap absorpsi bunyi sebab itu tidak menyalurkan energi bunyi, tetapi mereduksi gema dan pantulan bunyi .Difusor dibuat dari berbagai macam bahan. Manfred R. Schroeders' menemukan Difusor pertama kalinya pada tahun 1970. Difusor dapat dilihat pada kedua contoh dibawah ini pada Gambar 4. 


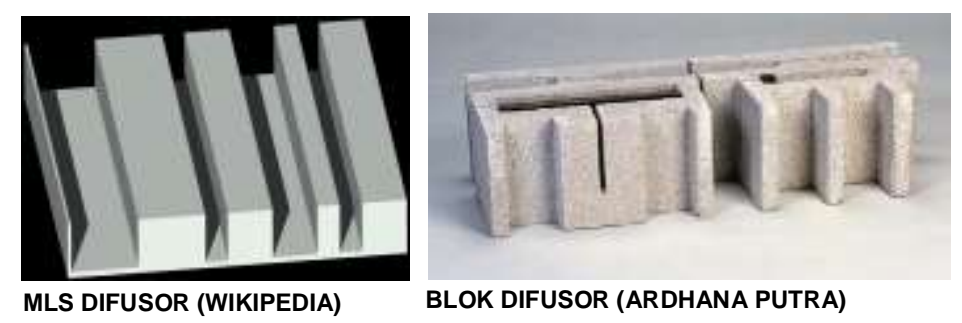

Gambar 4. Material Difusor

Besarnya penyerapan dapat diketahui dengan mengetahui koefisien penyerapan bunyi yang diberi lambang $\alpha$ dengan nilai dari 0 hingga $1 . \alpha=0$ berarti tidak ada penyerapan suara sedangkan jika $\alpha=1$ berarti seluruh (100\%) bunyi terserap, itu adalah lubang dinding (bukaan).
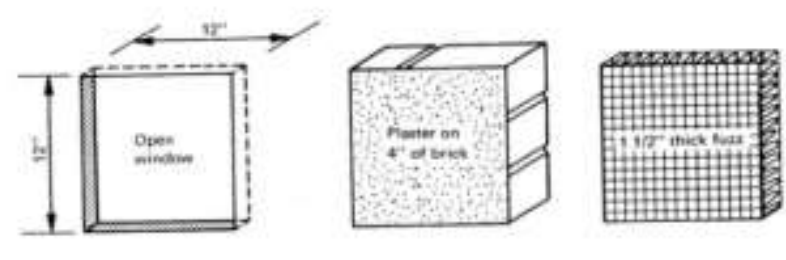

At $500 \mathrm{~Hz}$ toe 1 sa $\mathrm{ft}$ of the sbove witace condition

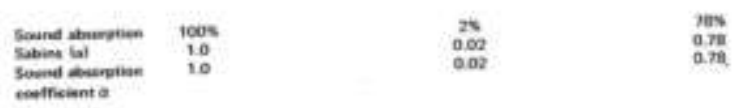

Gambar 4. Koefisien Serapan Bukaan Jendela, Dinding Bata, Fuzz (Serat penyerap serabutan) (Sumber: Egan, 1972)

Ketebalan panel penyerap bunyi juga sangat mempengaruhi besarnya $\alpha$ suatu bahan seperti dapat dilihat pada gambar dibawah ini.

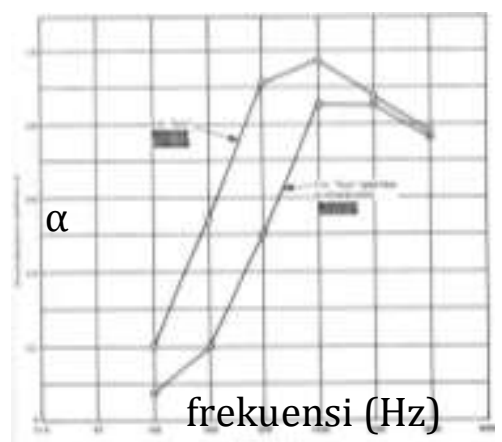

Gambar 5. Karakteristik Penyerapan dari Penyerap Membran

(Sumber: Egan, 1972)

Kemampuan menyerap bunyi dapat dilihat pada tabel koefisien serapan (absorption coefficient $\alpha$ ) berikut ini. 
Tabel 1. Data Penyerap Bunyi Bahan Bangunan, Perabot

(Sumber: Egan, 1972)

SOUND ABSORPTION DATA FOR COMMON BUILDING MATERIALS AND FURNISHINGS

\begin{tabular}{|c|c|c|c|c|c|c|c|}
\hline \multirow[b]{2}{*}{ Material } & \multicolumn{6}{|c|}{ Sound Absorption Coefficient } & \multirow{2}{*}{$\begin{array}{c}\text { NRC } \\
\text { Number* }\end{array}$} \\
\hline & $125 \mathrm{~Hz}$ & $250 \mathrm{~Hz}$ & $500 \mathrm{~Hz}$ & $1000 \mathrm{Hr}$ & $2000 \mathrm{~Hz}$ & $4000 \mathrm{~Hz}$ & \\
\hline \multicolumn{8}{|l|}{ Walle $(1,2,5)$} \\
\hline \multicolumn{8}{|l|}{ Sound-reflecting: } \\
\hline 1. Brick, unglated & 0.03 & 0.03 & 0.03 & 0.04 & 0.05 & 0.07 & 0.05 \\
\hline 2. Brick, unglazed and painted & 0.01 & 0.01 & 0.02 & 0.02 & 0,02 & 0.05 & 0.00 \\
\hline 3. Concrete bleck, painted & 0.10 & 0.05 & 0.06 & 0.07 & 0,09 & 0.08 & 0.05 \\
\hline 4. Cork on brick or concrete & 0.02 & 0.03 & 0.03 & 0.03 & 0.03 & 0.02 & 0.05 \\
\hline 5. Glass, heavy plate & 0.18 & 0.06 & 0.04 & 0.05 & 0.02 & 0.02 & 0.05 \\
\hline 6. Glass, typical window & 0.35 & 0.25 & 0.18 & 0.12 & 0.07 & 0.04 & 0.15 \\
\hline $\begin{array}{l}\text { 7. Gypsum boerd, 1/2-in. } \\
\text { paneling }\end{array}$ & 0.29 & 0.10 & 0.05 & 0.04 & 0.07 & 0.09 & 0.05 \\
\hline 8. Marble or glazed tile & 0.01 & 0.01 & 0.01 & 0.01 & 0.02 & 0.02 & 0.00 \\
\hline 9. Metal venetian blinds & 0.06 & 0.05 & 0.07 & 0.15 & 0.13 & 0.17 & 0.10 \\
\hline $\begin{array}{l}\text { 10. Plaster, sypeam of lime, } \\
\text { on brick }\end{array}$ & 0.01 & 0.02 & 0.02 & 0.03 & 0.04 & 0.05 & 0.05 \\
\hline $\begin{array}{l}\text { 11. Plaster, grpsum or lime, } \\
\text { on concrete block }\end{array}$ & 0.12 & 0.09 & 0.07 & 0.05 & 0.05 & 0.04 & 0.05 \\
\hline $\begin{array}{l}\text { 12. Plaster, gypum or lime, } \\
\text { on bth }\end{array}$ & 0.14 & 0.10 & 0.06 & 0.05 & 0.04 & 0.03 & 0.05 \\
\hline $\begin{array}{l}\text { 13. Hywood, S/3-ia paneling } \\
\text { 14. Wood, } / 4 \text {-in paneling. }\end{array}$ & 0.28 & 0.22 & 0.17 & 0.09 & 0.10 & 0.11 & 0.15 \\
\hline $\begin{array}{l}\text { 14. Wood, } 1 / 4 \text {-in. paneling, } \\
\text { with atr space behind }\end{array}$ & 0.42 & 0.21 & 0.10 & 0.08 & 0.06 & 0.06 & 0.10 \\
\hline \multicolumn{8}{|l|}{ Soundatisorbing: } \\
\hline $\begin{array}{l}\text { 15. Concrete block, coarse } \\
\text { 16. Cork, } 1 \text { in. with air space }\end{array}$ & 0.36 & 0.44 & 0.31 & 0.29 & 0.39 & 0.25 & 0.35 \\
\hline behind & 0,14 & 0.25 & 0.40 & 0.25 & 0.34 & 0.21 & 0.30 \\
\hline $\begin{array}{l}\text { 17. Lightweight drapery, } \\
10 \mathrm{ox} / \mathrm{sq} \text { yd, flat on wall } \\
\text { (note: sound-teflecting } \\
\text { at most frequencies) }\end{array}$ & 0.03 & 0.04 & 0.11 & 0.17 & 0.24 & 0.35 & 0.15 \\
\hline
\end{tabular}

\section{Hasil dan Pembahasan: Desain Panel Absorpsi Difusor Bunu}

Langkah awal dalam penelitian ini ialah mengadakan survei referensi standar luas bidang, ukuran di laboratorium kalibrasi Akustik di LIPI Serpong dan ITB Bandung selanjutnya mencari data desain sejenis dibeberapa perguruan tinggi seperti di UGM Jogyakarta, UNS Surakarta, Balai Besar Kerajinan Batik di Jogyakarta dan AKAS di desa Rantewringin Kebumen Jawa Tengah.

Hasil penelitian yang sudah dilakukan pada perguruan tinggi tersebut tidak berada di laboratorium karena dibawa pulang oleh para peneliti.

Penelitian dilakukan di workshop AKAS milik bapak Darda dan ibu Ismiwati di desa Rantewringin Kebumen. Gambar desain diberikan dilanjutkan dengan penyesuaian pengerjaannya terutama cara kerja yang mudah dipraktekan di daerah pemukiman pedesaan oleh masyarakat khususnya kaum wanita.

Ide awal adalah dengan mengembangkan panel dengan cara tenun seperti pada Gambar 6 di India yang ternyata tidak cocok karena terlalu masif ini tidak cocok sebagai bahan absorpsi bunyi begitu pula penampilannya didentifikasi masyarakat umumnya sebagai keset pintu. Berat panel tidak cocok dipasang pada dinding atau plafond.
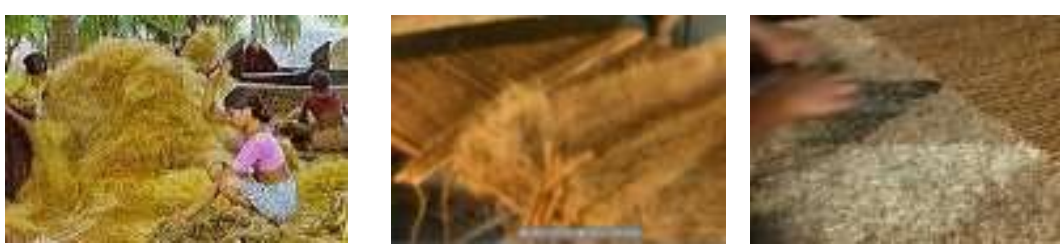

Gambar 6.Pembuatan Panel Bunu di India (Sumber: Wikipedia) 
Diputuskan untuk membuat panel dengan cara menyusun secara berlapis masing masing setebal 0,5 cm yang nantinya direkatkan dengan lem Latex kemudian disesuaikan ketebalannya sesuai ketebalan yang diinginkan .

\subsection{Desain Panel}

Dengan mempertimbangkan faktor berat, kelenturan, pengerjaan panel dari bahan bunu, maka ditentukan :

Ukuran : Panel indrabunu 01 sebagai dasar : Panjang $=100 \mathrm{~cm}$

$$
\text { Lebar }=100 \mathrm{~cm}
$$

Tebal $=2,5 \mathrm{~cm}$

Panel indrabunu 02

$$
\begin{aligned}
& \text { BidangDasar }=10 \mathrm{~cm} \times 10 \mathrm{~cm} \\
& \text { Tinggi }=7,48 \mathrm{~cm} \\
& \text { Sudut kemiringan sisi }=56^{\circ}
\end{aligned}
$$

Sesuai keperluan pengukuran di laboratorium Dengung, maka setiap jenis panel dibuat 12 lembar seluas $12 \mathrm{~m}^{2}$ untuk panel Indrabunu 01 dan 12 lembar Panel Indrabunu 02. Masing-masing jenis dibuat tambahan 3 lembar untuk cadangan jika ada yang rusak. Kita liha tgambar rancangan panel pada Gambar 7 berikut ini .
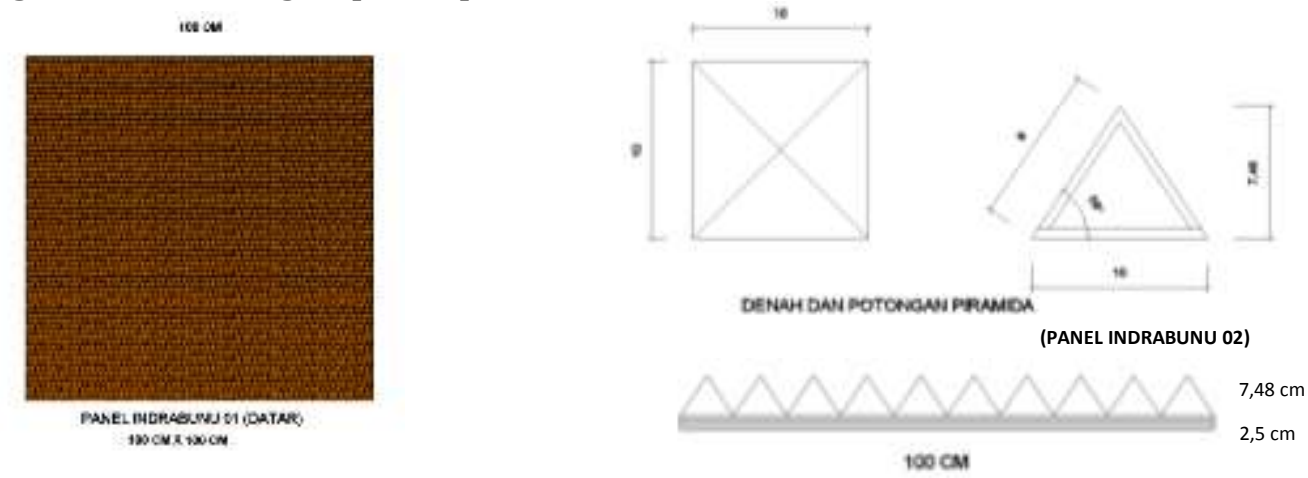

Gambar 7. RencanaUkuran Panel Indrabunu 01 dan 02

Lintasan energi bunyi yang menimpa panel datar dan piramida dapat dilihat seperti pada Gambar 8 berikut ini. Pada panel datar energi bunyi memantul dengan sudut yang sama dengan sudut arah datang. Energi bunyiakan terpantul dan sebagian terserap. Besarnya energi bunyi yang terpantul tergantung dari kerasnya bidang sedangkan besarnya energi terserap tergantung pada pori-pori yang ada pada bidang datar tersebut. Pada piramida energi bunyi terserap oleh sisi- sisi piramida disampingnya sehingga energy bunyi terpencar lemah.
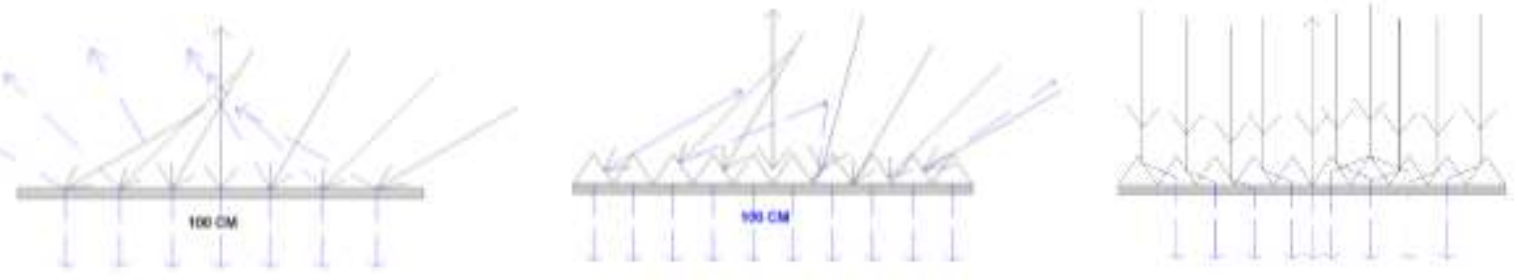

Gambar 8.Lintasan Bunyi pada Panel Datar dan Piramida

\subsection{Pengerjaan Panel Bunu}

\section{Panel Indrabunu 01}

Pengadaan bahan Bunu dengan membeli dari para petani kopra maupun dari rumah tangga, kemudian di uraikan dengan menggunakan mesin untuk 
memisahkan serat (coir) dan serbuk (peat). Yang dipaka iialah serat.Serat bunu dijemur selama cuaca cerah sehari. Tahapan pengerjaan dimulai dengan mempersiapkan alat perlengkapan cetakan dengan ukuran $202 \mathrm{~cm} \mathrm{x} 101 \mathrm{~cm}$ seperti pada Gambar 9 berikut ini.

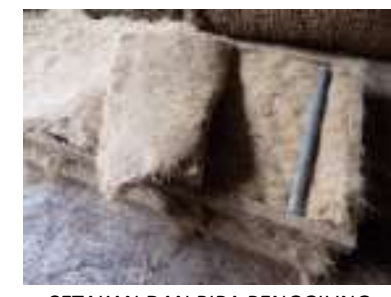

CETAKAN DAN PIPA PENGGILING

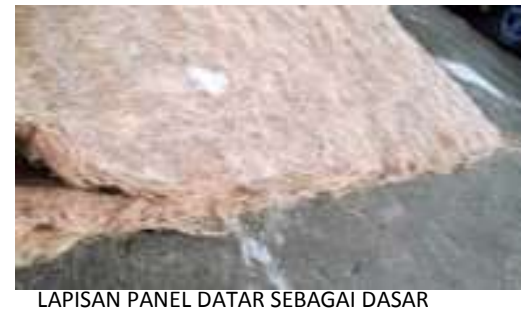

LAPISAN PANEL DATAR SEBAGAI DASAR

Gambar 9. Cetakan Panel dan Lapisan Panel Indrabunu 01

Setelah panel di beri lem, selanjutnya dipress dengan alat secara manual hingga merata dan padat seperti pada Gambar 10 dibawah ini, kemudian dijemur sampai lemnya mongering .Tahap berikut ialah merapikan pinggiran panel dengan cara membungkusnya dilem kemudian dipress lagi terakhir dijemur kembali.

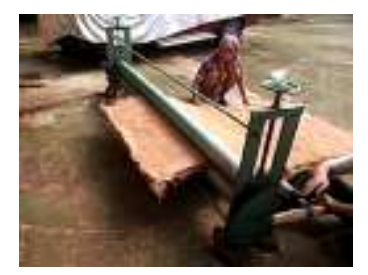

PANEL DIPRESS HINGGA MERATA

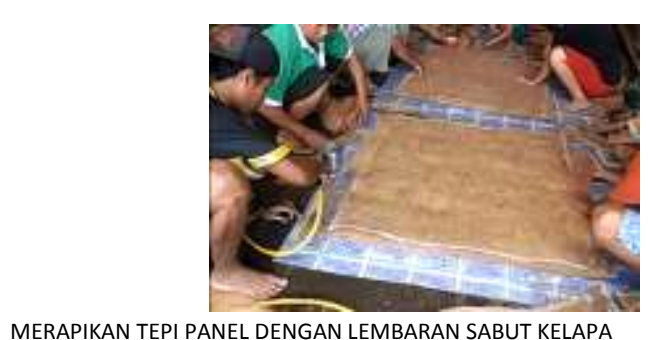

MERAPIKAN TEPI PANEL DENGAN LEMBARAN SABUT KELAPA

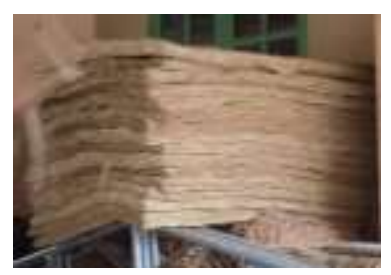

LEMBARAN PANEL SELESAI

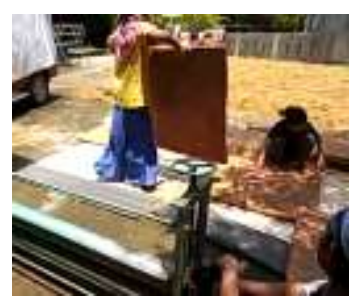

PENJEMURAN KEMBALI SETELAH DIPRESS

Gambar10. Proses akhir Panel Indrabunu 01

\section{Panel Indrabunu 02}

Piramida dibuat dengan membuat pola yang nantinya dilipa lalu dilem dengan latex. Lembaran tipis $0,5 \mathrm{~cm}$ dipotong kemudian diisi dengan coir supaya bisa menahan daya terpaan energi bunyi sehingga bentuknya tetap . Setelah piramidapiramida selesai dibuat sebanyak 100 buah untuk 1 panel maka dipasang dengan cara melekatkan dan ditempel diatas panel Indrabunu 01 sebagai dasarnya. Selesai dilekatkan panel ini dijemur untuk mengeringkan perekatnya.Itu bias dilihat pada Gambar 11 dibawah ini. 

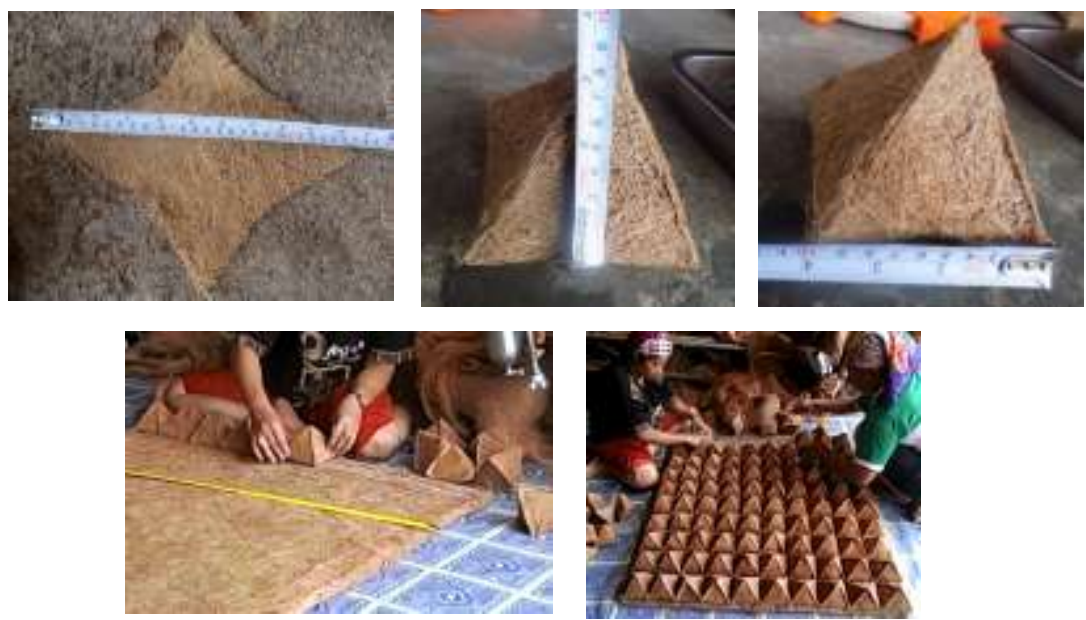

Gambar11. Proses Pembuatan Panel Indrabunu 02

\subsection{Pengukuran Kalibrasi NRC dan $\alpha$}

Panel-panel bunu sebanyak 30 lembar yang diisi didalam 5 buah peti berukuran 120 x 120 x tinggi $40 \mathrm{~cm}$, di kirim ke Laboratorium Akustik Pusat Penelitan Metrologi LIPI Serpong Tangerang Jawa Barat. Pengukuran dilakukan sebanyak 2 kali selama 2 hari. Proses pengukuran dapat dilihat di Gambar 12 berikut ini.
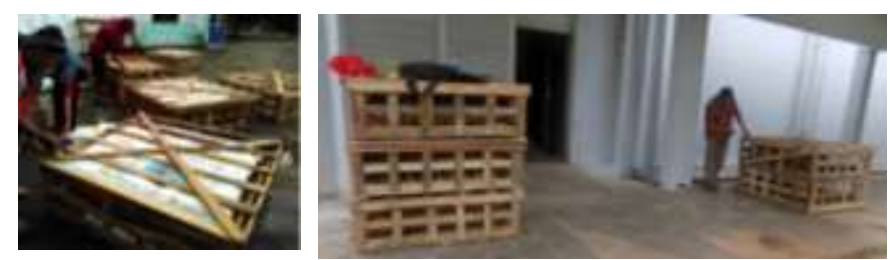

PANEL BUNU DI LABORATORIUM AKUSTIK LIPI SERPONG

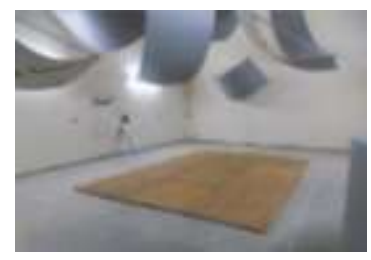

UJI LAB PANEL INDRABUNU 02 DI LAB. DENGUNG LIPI SERPONG

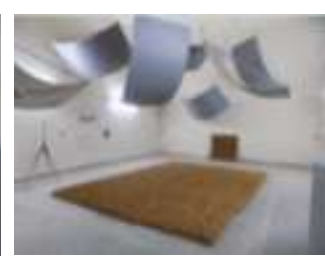

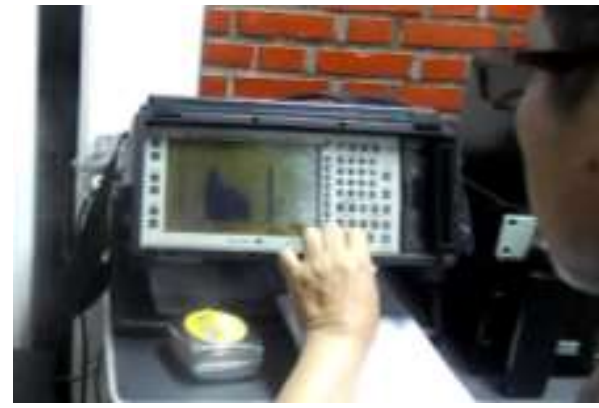

ALAT UKUR DUAL CHANEL REAL TIME FREQUENCY ANALYZER TYPE 2144

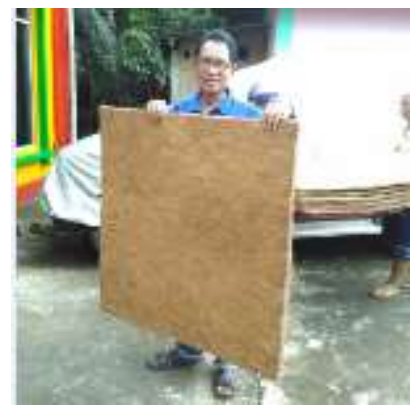

PANEL INDRABUNU 01

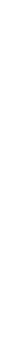

Gambar 12. Alat Pengujian Panel Indrabunu 01 dan 02 dan modulnya

\section{Hasil Uji Laboratorium}

Diambil $500 \mathrm{~Hz}$ untuk Pendengaran manusia normal.

1. Panel Indrabunu 01: Frekwensi $500 \mathrm{~Hz} \quad \alpha=0,37$

$$
\text { NRC } \quad=0,45
$$

2. Panel Indrabunu 02: Frekwensi $500 \mathrm{~Hz} \quad \alpha=0,59$

$$
\text { NRC } \quad=0,60
$$

Untuk lengkapnya hasil Uji Laboratorium di Laboratorium Akustik Metrologi LIPI Serpong dapat di baca pada lampiran. 


\section{Kesimpulan}

Panel Indrabunu 01 dan 02, dapat dipakai untuk auditorium kecil, teater rumah, ruang studio musik kecil, ruang karaoke. Untuk menambah nilai $\alpha$, perlu dibuat lebih tebal lagi dari 2,5 cm misalnya $3-5 \mathrm{~cm}$. Sebagai contoh penerapannya, jika sebuah ruangan untuk musik dengan tipe Sepmeyer B dengan rasio perbandingan Tinggi : Lebar : Panjang adalah 3,6 m : 4,6 m : 5,5 m . Terdiri dari 25,3 $\mathrm{m}^{2}$ Lantai keramik, 25,3 $\mathrm{m}^{2}$ Plafond Gipsum, 72,72 $\mathrm{m}^{2}$ Dinding Bata diplester (pintu kayu diasumsi plesteran), ada sofa dan 4 penonton, dengan memakai rumus Sabine $\mathrm{RT}=0,161 \frac{\mathrm{V}}{\mathrm{A}}$ detik.

Untuk ruang musik, RT yang direkomendasikan pada teater kecil ialah antara 1,2 - 1,4 detik. Jadi, RT = 0,161 $\frac{91,1}{5,38}=2,73$ detik, $>1,2-1,4$ detik,tidak memenuhi. Ketika dipasang, masing-masing $9 \mathrm{~m}^{2}$ panel indrabunu 01 pada kedua sisi dinding memanjang $18 \mathrm{~m}^{2}$, didapat $\mathrm{RT}=1,3$ detik, memenuhi.

Panel Indrabunu 02, dengan $\alpha=0,59$, maka hanya diperlukan $5 \mathrm{~m}^{2}$ pada masingmasing dinding memanjang semuanya $10 \mathrm{~m}^{2}$, didapat $\mathrm{RT}=1,32$ detik, memenuhi.

Desain Panel Absorpsi Difusor Bunu ini masih perlu dikembangkan, cara penataannya, pengerjaannya lebih rapi dan seragam, bentuk alternatif lainnya juga bisa dibuat serta ketebalan yang bisa mencapai nilai absorpsi maksimal.

Keuntungan dari cara pembuatan panel ini ialah dapat dibuat oleh siapa saja dimana saja, karena mudah pengerjaannya, bahannya tersedia di seluruh pelosok Nusantara, Diharapkan bahan baku sabut kelapa yang melimpah di Negara kita Indonesia dapat didesain sebagai bahan yang dimanfaatkan oleh masyarakat kita sebagai peluang kerja serta dapat diimpor sebagai bahan baku industri, teknik sipil.

\section{Daftar Pustaka}

1993, Laporan Pekerjaan Pengujian Nilai Peredaman Bunyi Dari Beberapa Bahan Bangunan, Puslitbang Kalibrasi, Instrumentasi dan Metrologi Lembaga Ilmu Pengetahuan Indonesia, Serpong

Beranek L.Leo. 1962. Music, Acoustics \& Architecture, John Wiley \& Sons, INC, New York, London

Egan David, 1972, Concepts in Architectural Accoustics, Mc Graw-Hill Book Company, New York, Duseldorf etc.

Everest A.F., 2001, The Master Handbook of Acoustics, McGraw-Hill, New York, San Francisco, Washington DC etc.

George, I.C.1977, Theater Design, McGraw Hill.Inc. USA

Madan, M., James, J., Rocafort. Architectural Acoustics: Principles and Design, Prentice Hall, Inc, New Jersey

Makainas Indradjaja, 2011, Kompartemen Akustik Ruang, Penelitian DIPA . No. 0748/023-04.2.01/27/2011 Universitas Sam Ratulangi, Manado

Makainas Indradjaja, Siti Handjarinto, Finaryah Lego, 2010, An Acoustics Investigation into Small Theatre in Indonesia, Proceeding of 20th International Congress on Acoustics, ICA 2010, Sydney Australia

Makainas, I., 2008, Thesis, Pengaruh Desain Auditorium Terhadap Waktu Dengung, Universitas Indonesia, Depok

Parkin P.H \& Humpreys, H.R, 1969, Acoustics Noise and Buildings, Faber and Faber LTD, 24 Russell Square, London.

Peter, L. \& Templeton Duncan, 2001, Detail Akustik, Erlangga, Jakarta.

Putra Ardhana, I.B. 2008, Bahan Presentasi Seminar Akustik, ITB. Bandung

SARWONO JOKO, 2008, Akustika Ruangan htm. Fenomena Akustik dalam Ruang Tertutup. 
Saunders David \&Templeton Duncan, 1987, Acoustic Design, The Architecture Press, London.

Zhang Yan, 2005, A Method to Predict Reverberation Time in Concert Hall Preliminary Design Stage, Georgia Institute of Technology.

\section{LAMPIRAN}

1. Pengukuran Koefisien absorpsi $\alpha$ dan NRC Panel Indrabunu 01. 2 .

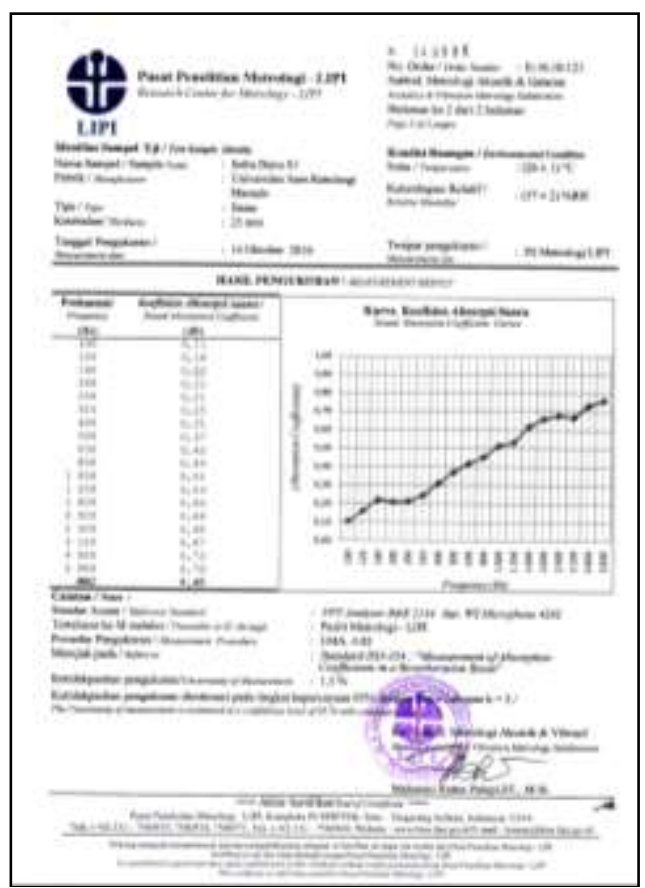

3. Pengukuran Koefisien absorpsi $\alpha$ dan NRC Panel Indrabunu 02.

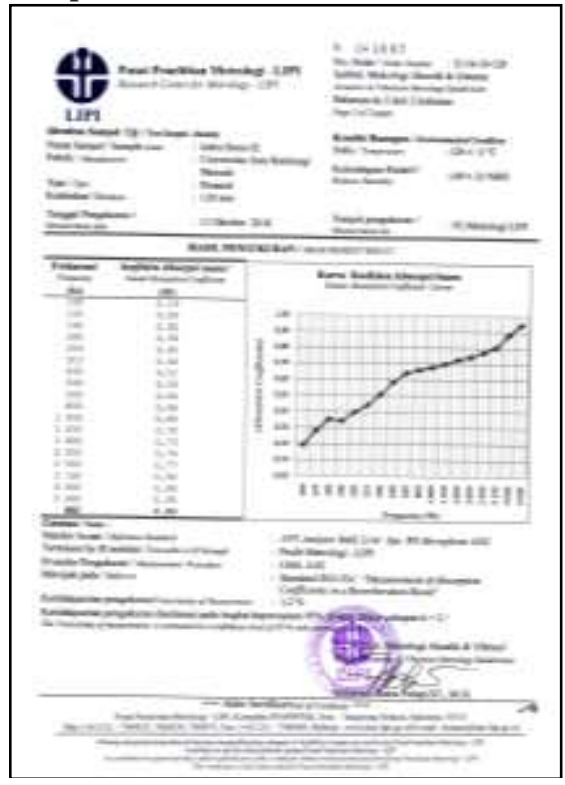

